\title{
nature
}

\author{
25 June 1981
}

\section{Congress and cancer research}

Has the United States Congress, having declared "war on cancer" ten years ago, now decided to declare war on the National Cancer Institute? This speculation has run through the biomedical research community since the extraordinary occasion three weeks ago when the director of the institute, Dr Vincent T. DeVita, was hauled over the coals by the Senate Committee on Labor and Human Resources (see Nature, 11 June, p.444), one of the several committees in Congress which have in the past decade cheered on the institute's growth. The committee was the platform from which, in the early 1970s, Senator Edward M. Kennedy sought to outbid the then Administration in generosity towards cancer research. Now, Senator Kennedy finds himself in the unfamiliar role of senior minority member of the committee, subject to the tutelage of Senator Orrin G. Hatch, apparently bent on winning his spurs in the Senate by being a conspicuous and good Republican - eliminating "waste", diminishing the "role of government" and so on. But Dr DeVita was not merely the victim of a change of political style.

So much seems implicitly to have been acknowledged by Dr DeVita's colleagues at the National Cancer Institute, who put out a statement last week praising his qualities both as a scientist and an administrator. Everybody, at the institute and elsewhere, is agreed that Dr DeVita's appointment as director on 1 January brought a breath of fresh air to an institution in danger of drifting complacently with the tide of congressional largesse. $\mathrm{He}$ commands the professional respect of his colleagues, but he is also energetic and tough. It would be disastrous for one of the most important of all federally supported scientific institutions if the Senate committee, or some other zealous custodian of the public purse, were at this stage needlessly to interfere with Dr DeVita's chance of making a success of the National Cancer Institute. The particular issues with which he was confronted three weeks ago the discovery of irregularities in the conduct of research contracts let by the institute - are acknowledged to have their origins in relatively ancient history. To the extent that the National Cancer Institute is at all responsible, the blame should rest with $\mathrm{Dr}$ DeVita's predecessors. His own fault - which some might think a virtue - at the hearing three weeks ago was that of political innocence. He seemed not fully to have appreciated that the first duty of any public servant before a congressional committee is to affirm that his every waking hour is spent on saving every possible nickel of taxpayers' money. Only when that has been done is it permissible for him to think of prosecuting the task for which his budget has been set aside, "curing" cancer or whatever it may be.

So far, there is no knowing what the new Senate Committee on Labor and Human Resources has at the back of its collective mind. The complaints against the institute brought up by Senator Hatch were hardly new. Some of them had been rehearsed before Representative Albert Gore's subcommittee in the House of Representatives some weeks earlier. But, in any case, why should the National Cancer Institute itself be blamed if one of the several investigators working on a collaborative clinical research contract has been accused of keeping inadequate or even falsified medical records? (The investigation of these allegations by the National Institutes of Health will not be complete until after the summer.) Dr DeVita was embarrassed three weeks ago because he had not blackballed a further grant to the same researcher, on the principle of "innocent until proven guilty". But who, in Congress of all places, would expect a good administrator to behave differently? So why did Senator Hatch hold his inquiry at all, and then assiduously leak the details of his complaints in advance to the daily press? Can there be so much smoke and no fire?

Time will tell, probably quite quickly. The unexpected resignation of Dr Donald Fredrickson as director of the National Institutes of Health (of which the National Cancer Institute is one) will be a chance for finding out (see page 603). Although it will be necessary to read the tealeaves before knowing what to make of the White House's nomination of a successor to Fredrickson, Senator Hatch's committee will no doubt seize the opportunity for saying where it stands on continued public support for biomedical research and for cancer research in particular. The greatest danger, in the period immediately ahead, is that the naivety that inspired the war on cancer ten years ago will be found still to persist. Already, some members of the Hatch committee have been asking aloud why, after a decade's generous spending, cancer has not yet been "cured". More generally, the persistence of rheumatoid arthritis, cardiovascular disease or even death itself has lent weight to the popular suspicion that good health is not one of the products of research. Congress, more than usually eager to do the work of the Office of Management and Budget, could easily become jaundiced.

Of necessity, neither obduracy nor round robins in support of Dr DeVita will meet the need. More to the point would be a determined attempt to clear up the misunderstanding between Congress and the research community on the function of cancer research. The notion that there is a war to be won is foolish - and springs largely from the politicians. While the National Cancer Institute has direct responsibility for several important programmes directly related to the improvement of various cancer treatments, the most promising part of its work remains its long-term research, only some of which is ever likely to help with the treatment of specific types of cancer. Congress must somehow be helped to appreciate this simple truth. The task would be easier if it were also more widely appreciated in Congress that the basic research programmes of several of the constituent institutes of the National Institutes of Health are essentially part of a cooperative effort, aimed at the understanding of cell biology and physiology that will, on past experience, make possible as yet unknown treatments for possibly unrecognized illnesses. Administratively, that argues for closer relationships between the several institutes and for flexibility in the disposal of their separate budgets. In the past few years, unfortunately, Congress has been pushing in the opposite direction, seeking more direct control over individual institutes. One consequence is that people like Dr DeVita, appointed as scientists, find themselves dealt with in Congress as if they were nothing but accounting officers. The time has come to reverse this tendency.

\section{No Irish science politics}

The assumption that science and politics do not mix is only occasionally falsified. The dangers in too rigorous an attachment to the principle is that it may make a nonsense of the practice. This is what the Science Research Council (now even more augustly known as the Science and Engineering Research Council) has just done. For the council has turned down an innocuous proposal that there should in future be an exchange of graduate students between the United Kingdom and the Irish Republic on the modest scale of a dozen or so a year. By all accounts, the council wishes this modification of pure chauvinism to be subsumed in an 